\title{
Potrč v Pleteršnikovem slovarju (Roman Na kmetih, 1954)
}

\author{
Melita ZEMLJAK JONTES \\ ALENKA VALH LOPERT \\ Univerza v Mariboru, Filozofska fakulteta, Koroška cesta 160, \\ SI-2000Maribor,melita.zemljak@um.si, alenka.valh@um.si
}

\begin{abstract}
Prispevek na osnovi primerjalne analize prikazuje besedje, zapisano v Potrčevem romanu Na kmetih iz leta 1954, in zapise v Pleteršnikovem Slovensko-nemškem slovarju iz let 1894-1895. Glede na Potrčev slovarček 89 narečnih geselskih iztočnic na koncu romana je iz analize razvidno, da 52 od teh izkazuje narečno rabo v Pleteršnikovem slovarju.
\end{abstract}

The article is based upon comparative analysis presenting the vocabulary, written in Potrč's novel Na kmetih (The Land and the Flesh) (1954), and the entry cues in the Pleteršnik's Slovensko-nemški slovar (Slovenian-German dictionary) (1894-895). According to the author's glossary of 89 dialect dictionary entries at the end of the book, the analysis shows that 52 of them have the same dialectal use also in the Pleteršnik's dictionary.

Ključne besede: Potrč, Na kmetih, Pleteršnik, prleško narečje

Key words: Potrč, Na kmetih, Pleteršnik, the Prlekija dialekt

\section{Izhodišče analize}

Gradivo za analizo predstavlja Potrčev roman Na kmetih (1954), katerega besedje je bilo preverjeno v dvojezičnem Pleteršnikovem Slovensko-nemškem slovarju (1894/1995 oz. v spletni izdaji iz leta 2010).

\subsection{O Pleteršnikovem slovarju}

Pleteršnikov Slovensko-nemški slovar je nastal kot slovarsko naročilo škofa Pogačarja leta 1880, in sicer Levstiku s sodelavcema Levcem in Pleteršnikom. 
Vendarle je Pleteršnik postal edini pripravljalec slovarskega gradiva in tako je leta 1883 prevzel uredništvo nabranega gradiva, na katerem je delal kar dvanajst let, in pripravil eno najpomembnejših slovarskih del do tedaj. ${ }^{1}$ Pomen Pleteršnikovega slovarja so poudarjali številni jezikoslovci pa tudi literarni zgodovinarji: ${ }^{2}$

Avgust Pirjevec (1924: 368, 371) je v Ljubljanskem zvonu zapisal, da je »iz kaotičnega gradiva zgradil Pleteršnik harmonično stavbo in ji vdahnil življenje« ter da je »dovršil ... stavbo, katero so gradile generacije slovenskega rodu in kronal delo neštetih slovenskih rok.«

Rudolf Kolarič (1974: i) je pisal o aktualnosti v jezikoslovni stroki: »Ta slovar še vedno nudi toliko izredno zanimivega in bogatega gradiva, ne samo za slovenskega, marveč za vsakega slovanskega lingvista.«

Marija Mercina (1997: 63) je izpostavila pomen SSKJ in Pleteršnikovega slovarja: »[O]dkar je izšel zadnji, 5. del SSKJ, raje pogledamo vanj, ko razlagamo pomen besed in njihovo slogovno vrednost, Pleteršnik pa je ostal ključ za spoznanja o življenju besed.«

Franc Jakopin (1983: 273) je poudaril vsestransko trajno vrednost slovarja, saj so »iz Pleteršnika črpali vsi, ki so se v 20. stoletju tako ali drugače ukvarjali s slovenskim jezikom: naj gre za pisatelje, kritike in prevajalce ali za jezikoslovna dela.«

Stane Suhadolnik (1989: 115) pa je slovar, ki je nastal na prelomu 19. v 20. stoletje, postavil v sodobnost konca 20. stoletja: »Delo je še vedno živ studenec naše govorice, « z njim je Pleteršnik opravil pomembno nacionalno nalogo »sestaviti svojemu ljudstvu slovar, ki bi v celoti zajel in ohranil njegovo največje bogastvo in ki bi se z njim potrdilo njegovo bitje in žitje«.

\subsection{0 avtorju in vpogled $v$ roman $\mathrm{Na}$ kmetih}

Ivan Potrč (1913-1993) se je rodil v Štukih pri Ptuju kot drugi otrok v kmečki družini desetih otrok. Osnovno šolo in gimnazijo je obiskoval na Ptuju, z gimnazije pa je bil nekaj mesecev pred maturo zaradi političnega delovanja izključen in v Ljubljani zaprt. Po prestani ječi je nekaj časa živel doma, se pred drugo svetovno vojno preselil v Ruše, deloval kot novinar pri Mariborskem večerniku (1938-1939), po 2. svetovni vojni pa nato kot dolgoletni urednik in direktor Mladinske knjige ter član CK ZKS. Na začetku 2. svetovne vojne so ga Nemci zaradi ilegalnega dela proti okupatorju poslali v koncentracijsko taborišče Mauthausen, od koder se je vrnil leto dni kasneje, a bil zaradi vrnitve komunističnemu političnemu vrhu sumljiv, ne glede na to, da je odšel v partizane.

Ivan Potrč je literarno ustvarjal od gimnazijskih let in se počasi, a vztrajno, političnim težavam navkljub uveljavljal v slovenskem in takratnem jugoslo-

${ }^{1}$ Furlan: http://isjfr.zrc-sazu.si/pletersnik/. Pridobljeno 10. 5. 2014.

${ }^{2}$ Avgust Pirjevec (1924: 368, 371), Rudolf Kolarič (1974: i), Marija Mercina (1997: 63), Franc Jakopin (1983: 273), Stane Suhadolnik (1989: 115) so navedeni po Furlan: http:// isjfr.zrc-sazu.si/pletersnik/. Pridobljeno 10. 5. 2014. 
vanskem, tudi tujem prostoru, na kar kažejo številna priznanja in sprejetje v SAZU kot rednega člana (Čeh Steger 2012: 277-278; Koblar/SBL 2013; Ivan Potrč, Wikipedija).

Ivan Potrč je ustvaril dela z najraznovrstnejšo tematiko, povsod pa je skušal prikazati malega človeka, njegovo težko (večinoma kmečko) življenje, polno pomanjkanja in trdega dela, podkrepljeno z izostrenim čutom za človeško usodo. Še posebej izstopa njegova človeška in pisateljska povezanost s Ptujskim poljem, Halozami in Slovenskimi goricami (Čeh Steger 2012: 278).

Roman $N a$ kmetih je izšel pri Slovenski kmečki zvezi leta 1954 v obsegu 236 strani. Po splošni sodbi predstavlja enega vrhuncev Potrčevega pisateljskega ustvarjanja. Avtor v njem idejno in slogovno združuje vse sestavine svojega proznega pisanja in potenciranja do najbolj zgoščene oblike (Mevlja 1993: 15). Stanko Janež prišteva roman med temeljna dela slovenske književnosti in ga postavi za temeljni kamen v ustvarjanju slovenskih psiholoških romanov s kmečko tematiko (prav tam). Leta 1968 Slodnjak v Slovenskem slovstvu zapiše svoje poglobljeno razmišljanje o romanu (Gerlanc 1969: 3):

\begin{abstract}
Pomemben dokaz za to, kako je Potrč čedalje bolj premagoval ozko družbenopolitično gledanje in presojanje slovenjegoriškega gruntarstva, je roman $\mathrm{Na}$ kmetih. V tej okvirni pripovedi o spolnem izživljanju povprečnega kmečkega fanta, ki ga gibljeta v glavnem samo misel na grunt in na žensko, je pustil socialno problematiko na obodu ter se je z nenavadnim vživetjem poglobil v emocionalno predvsem erotično-seksualno stran junakove duševnosti. Pri tem ni zamolčal zunanjih povodov, ki so pospeševali prebujanje in razraščanje fantove strasti, vendar pa je z največjo pozornostjo zapisoval njegovo notranje dogajanje. - Priznati moramo, da je ustvaril v romanu nove in zanimive človeške figure in da je skoz nje prodirno osvetlil sodobno moralno življenje kmečkega prebivalstva v ptujski okolici. ${ }^{3}$
\end{abstract}

Roman je doživel veliko prevodov v tuje jezike, npr. že leta 1955 v italijanščino (Terra e donne, prevajalka Mija Kalan), v angleški jezik pa leta 1969 (The Land and the Flesh, prevajalec Henry Leeming). Angleški prevod je nastajal $\mathrm{v}$ sodelovanju s pisateljem in pisateljevim bratom, $\mathrm{z}$ ogledi haloških goric, $\mathrm{s}$ poimenovanjem bivališč in vsega v njih, vsega, s čimer so se ljudje ukvarjali (Gerlanc 1969: 3).

\footnotetext{
${ }^{3}$ V sami zgodbi romana gre za izpoved Južeka Hedla v ječi o tem, kaj se mu je zgodilo. Zaradi spora s sestro Lizo in z njenim možem Štrafelo, tudi z materjo glede domače posesti, Južek zapusti domačijo in se kot hlapec zaposli na sosednji kmetiji Toplekovih. Tu se spolno (in ne ljubezensko) zaplete najprej s starejšo Toplečko, ki mu rodi otroka, nato pa ga omreži še Hana, starejša Toplečkina hči, predvsem zaradi strahu, da se Toplečka po smrti moža in gospodarja z Južekom ne bi poročila in bi mu pripadla kmetija; tudi Hana zanosi. Ko Južek spozna, da nikoli zares ne bo mogel postati gospodar domače hiše in zaradi Toplečke ne bo mogel postati niti gospodar na sosednji kmetiji, ob spletu okoliščin Toplečko zadavi, zaradi česar je obsojen na zapor. Tunika se v romanu pojavi le nekajkrat, Južek se vanjo zagleda, a se med njima ne razvije niti spolno niti ljubezensko razmerje, kljub temu da ob koncu romana bralec izve, da je Tunika Južeka ljubila. Hana ostane z dvema otrokoma, z materinim in s svojim, ter čaka na Južekovo vrnitev iz zapora.
} 
Prostor in čas sta v romanu nedorečena in izolirana, saj le Štrafela, miting pri Ploju in Hanino vprašanje, ali še silijo ljudi v zadruge, nakazujejo okvirno krajevno in časovno umestitev (Štih 1954: 855). Dogajanje na Toplekovini se sicer ne povezuje z zunanjim dogajanjem v družbi, iz česar se svet na Toplekovini kaže kot idila, ne glede na vse negativno, kar se zgodi. To je razvidno tudi iz avtorjevega zapisa o romanu (Potrč 2004: 5):

Takoj skraja moram povedati nepoznanemu bralcu, ki bo kdaj prebiral te liste, da jih ne bi nikdar popisoval, če ne bi v kajhi, kjer sem tudi sam sedel, naletel na nekega kmečkega poba, doma s Štajerske /.../.

\section{Umestitev narečja iz knjige $v$ narečno skupino}

Ivan Potrč je odseval razgibanost pokrajine in odnosov med ljudmi tudi v jeziku svojih del (Čeh 2006b: 17), saj je:

svojo materinščino, kakor je poimenoval štajersko slovenščino, branil /.../ in /.../ znal odgovoriti, da je tako moral pisati, če je hotel ostati zvest svojemu človeku, njegovemu mišljenju, čustvu in nagonu, skratka, če je hotel kar najbolj živo in pristno pisati o kmečkem, bajtarskem ali kočarskem življenju, kakor ga je doživljal in spoznaval na območju Ptujskega, Dravskega polja, Haloz in Slovenskih goric. Potrčevi zapisi o jeziku razkrivajo, da se je v javnem življenju vedno zavzemal za knjižno slovenščino in da je v literaturi zagovarjal pokrajinsko in narečno besedo le tedaj, ko ta živo razkrije človekovo misel, čustvo in strast.

Poudarjal je pristnost narečne besede in kritiziral t. i. hoteno narečništvo, literarno novacijo, saj se mu je zdelo za lase privlečeno. Iz dela je moč razbrati, da gre geografsko za območje Štajerske, ki ga domačini uporabljajo tudi za poimenovanje govora (Čeh 2006b: 17):

Potrč piše o svoji »štajerščini« glede na geografsko razdelitev Slovenije, jezikovno spada to okolje v prleško narečje.

Iz današnje geografske ${ }^{4}$ in sploh upravne ${ }^{5}$ delitve Slovenije na pokrajine sodi tudi del Dravske doline v okolici Ptuja v okvir Štajerske. Ta delitev zagotovo izhaja iz zgodovine upravne delitve slovenskega naselitvenega prostora $\mathrm{v}$ okviru

\footnotetext{
${ }^{4}$ Vir: http://sl.wikipedia.org/wiki/Pokrajine_v_Sloveniji. Pridobljeno 10. 5. 2014.

${ }^{5}$ V 17. členu Predloga zakona o ustanovitvi pokrajin, pripravljenega s strani Službe vlade RS za lokalno samoupravo in regionalno politiko in potrjenega s strani Vlade Republike Slovenije 10. 7. 2008, je zapisano, da se ustanovi Vzhodnoštajerska pokrajina, ki obsega občine: Cirkulane, Destrnik, Dornava, Gorišnica, Hajdina, Juršinci, Kidričevo, Majšperk, Markovci, Ormož, Podlehnik, Ptuj, Središče ob Dravi, Sveti Andraž v Slovenskih goricah, Sveti Tomaž, Trnovska vas, Videm, Zavrč, Žetale. Sedež pokrajinskega sveta Vzhodnoštajerske pokrajine je v Ormožu, sedež pokrajinske uprave je na Ptuju. Vir: http://www.arhiv.svlr.gov.si/si/delovna_podrocja/podrocje_lokalne_samouprave/ pokrajine/pokrajine_arhiv/index.html. Pridobljeno 10. 5. 2014.
} 
Avstro-Ogrske, obravnavano območje je namreč upravno sodilo v avstrijski del monarhije.

Na karti slovenskih narečij (Ramovš 1931) je območje opredeljeno kot štajersko, »severno-vzhodni štajerski dialekti«, razdeljeni na »goričanski, prleški in prekmurski dialekt«. Prleško narečje sodobna dialektologija (Logar, Rigler 1993) umešča v panonsko narečno skupino.

Poimenovanje pokrajine in narečja izhaja iz pogostnega prislova $p r v$-ie 'vorher, früher' $\rightarrow$ prvl'e $\rightarrow$ 'prle (Zorko 1998: 50). Obravnavano območje sodi v zgornjeprleški govor. O prleškem narečju je pisalo kar nekaj raziskovalcev, natančneje Fran Ramovš, Rudolf Kolarič, Jakob Rigler, v zadnjem času pa Zinka Zorko, Mihaela Koletnik, Bernard Rajh, Jožica Škofic idr. ${ }^{6}$

Za govore prleškega narečja (Zorko 2009: 241-242) velja, da so izgubili tonemsko nasprotje, naglas je jakostni, doživeli so vse slovenske naglasne pomike in tudi zanje velja splošni slovenski zakon o odvisnosti samoglasniške kakovosti od mesta in kolikosti naglasa ali samoglasnika; naglasno mesto je praviloma isto kot v izhodiščnem sestavu, drugi naglasni umik s kračine zadnjega zloga na $e$, $o$ in polglasnik je izveden, novonaglašeni samoglasnik je praviloma še kratek.

Naslednja opredelitev poimenovanja velja tudi za dogajalni prostor v romanu (prav tam):

Prebivalci analiziranega markovskega govora se ne imenujejo Prleki, pač pa so Štajerci, po nekdanjem poimenovanju dežele Štajerske, ki je segala do Mure.

\section{Jezik romana}

Potrčev roman Na kmetih (1954) je pisan v slovenskem knjižnem jeziku. Narečnost se kaže le v besedišču in v nekaterih glasoslovnih značilnostih (zapisani naglasi) teh narečnih besed z Dravskega polja (čúnika, fáčuk, kámenščnice, kánkole, pócje, rájce, sčájmati se, štalínke, večérko idr.). Sam avtor je na koncu romana zapisal slovarček 89 narečnih besed, ki jim je dopisal knjižni pomen; vir zapisanih pomenov ni naveden, zato je sklepati, da gre za pomen besed kot del avtorjeve narečne kompetence. Avtor sam (Potrč 2004: 256) je na začetku slovarčka zapisal:

Ker je zaradi preprostega pripovedovanja ostala marsikatera beseda pristno izražena, bo zapisovalec te zgodbe po svoje razložil nekaj preveč domačih besed.

O Potrčevem jeziku lahko beremo:

- pri Mevlji (1993: 10): Njegov literarni jezik je izviren in barvit, bogat in poln narečnih izrazov. Slovi kot pozoren in tenkočuten oblikovalec malih, socialno bednih in moralno ogroženih človeških, zlasti kmečkih, usod iz severovzhodne Slovenije (Prlekije);

${ }^{6}$ F. Ramovš (1904); R. Kolarič (1956, 1968); J. Rigler (1981); Z. Zorko (2009); M. Koletnik (2007); B. Rajh (1999, 2002, 2003, 2004a, b, 2005a, b, 2006, 2008, 2010); J. Škofic (2004). 
- pri Čeh (2006b: 19): V knjižni jezik Potrčeve pripovedne proze se najopazneje vpletajo narečne besede, ob tem še nekoliko arhaizirano besedišče, pogovorni jezik, jezik uradnika, kmeta, dninarja, kočarja, delavca, berača idr. Vsi ti jezikovni podkodi ustvarjajo jezikovno raznoličnost in bogastvo Potrčeve pripovedne proze. Narečno besedišče sidra pisatelja in njegove literarne osebe v pokrajinsko prepoznaven in zamejen prostor Ptujskega, Dravskega polja, Haloz in Slovenskih goric, to je tudi prvinski jezik pisatelja in njegovih oseb, jezik, skozi katerega se izraža njihov pogled na svet, zato je to obenem tudi edini jezik, s katerim je lahko avtor najpristneje oblikoval podobo svojega človeka;

- prav tam: ... /M/ož govori o svoji ženi kot o babi, najde žena za moža še celo vrsto slabšalnih izrazov, kot so ded, krevs, stari trap, cunja, staro kresalo, stara zapita slakota idr. Osebe imajo pokrajinsko značilna imena (Franček, Tinek, Tonek, Karlek, Lizika, Južek, Janžek, Lojzek, Štefek; Fanika, Lizika, Tunika, Milika, Hanika, Trezika, Malika). Po poroki se dekleta kaj hitro spremenijo v babe, njihovo ime lahko dobi tudi slabšalno priponsko obrazilo (Trezika je Trezanja, Hanika postane Handrača), najpogosteje pa so poimenovane z žensko obliko moževega priimka, ki spreminja žensko v moževo lastnino in obenem zbuja negativne konotacije (Malečka, Lenarčka, Toplečka, Hedlca, Merčevka, Kejačka, Hrgovca) ...;

- prav tam: ... Ivan Potrč v prispevku Zapis o besedi navaja, da je ob nekem poskusu, da bi njegovi kočarji in dninarji govorili knjižni jezik, kaj hitro ugotovil, da so postali ponarejeni, pusti in mrtvi.

\section{Analiza}

V romanu Na kmetih je Potrč sam na koncu romana sestavil slovarček 89 narečnih besed, kakor jih je občutil on sam, ter jih pojasnil. 70 besed je zaznamovanih z naglasom, in sicer bodisi zaradi različnega mesta bodisi vrste naglasa besed glede na knjižno normo. V pregledu besedja slovarčka je najprej zapisana avtorjeva razlaga (Po), sledi razlaga besedja po Pleteršnikovem Slovensko-nemškem slovarju (Pl). V oklepaju pred navedbo vira je zapisan zapovrstni pomen v slovarju, za poševnico pa število vseh pomenov posamezne geselske iztočnice. Če je zapis naglasa od zapisanega v Potrčevem slovarčku drugačen bodisi v mestu ali vrsti naglasa (kvaliteti in/ali kvantiteti) bodisi v spolu, številu, določnosti pridevnika, je geselska iztočnica zapisana krepko pred razlago iz posameznega slovarja. Besede, ki so v Potrčevem slovarčku zapisane v neosnovni obliki, so bile v slovarju preverjene tudi v svoji osnovni obliki.

Od 89 besed je 67 samostalniških besed, 8 pridevniških besed, 10 glagolov in 4 so prislovi.

\section{Gradivo: $^{7}$}

bábica - nakovalce, na katerem klepljejo (Po); bábica, f. železo, na katerem se kosa kleplje, der Dengelstock; (14/16; Pl);

\footnotetext{
${ }^{7}$ Besede od bábica do vključno ópravka so bile natančno tudi primerjalno s SSKJ in SP analizirane v prispevku Potrčev roman $\mathrm{Na}$ kmetih v Pavlovićevem celovečernem filmu Rdeče klasje (Valh Lopert, Zemljak Jontes 2013).
} 
blánja - deska, plužna deska, ki obrača brazdo (Po); blánja, f. mala gredica, Pliskavica (Kras) $(2 / 3 ; \mathrm{Pl})$;

ceketáti - (sračji ceket) (Po); ceketáti -etâm, -ęčem, vb. impf. = čeketati, C. (1/1; Pl);

črmljen - rdečkast $(\mathrm{Po}) ;(-\mathrm{Pl})$;

čúnika - mlada svinja $(\mathrm{Po}) ;(-\mathrm{Pl})$;

dójva - molža (Po); (- Pl);

doklič - dokler (Po); dòklič, conj. = dokler, Habd.-Mik., C., vzhŠt., ogr., kajk.; Jejmo 'no pijmo, Doklič še zdravi smo mi, Danj. (Posv. p.). (1/1; Pl);

fáčuk - nezakonski otrok (Po); fâčuk, $m$. uneheliches Kind, ogr.-C., M., kajk.-Valj. (Rad); tudi: fačúk, kajk.-Valj. (Rad); — prim. madž. fattyú, Mik. (Et.). (1/1; Pl);

gántnarji - tramovi za sode v kleteh (Po); (- Pl);

gárce - lestve na lažjem vozu, lažji voz z lestvami (Po); (- Pl);

góž - vez za oje na jarmu (Po); gộ̌ $\check{z},-\hat{\imath}, f$. der Jochriemen, die Jochwiede, die die Deichsel an dem Joche festhält, Cig., Jan., M., Met., Štrek., Št.; (gož, m. Tolm.-Erj. [Torb.]); — das Pflugband, das den Pflugbalken mit dem Radgestell verbindet, Z. (3/3; Pl);

grólike - jagode na molku (Po); (- Pl);

jarčiti se - pariti se (Po); járčiti, jârčim, vb. impf. bespringen (vom Bock, Widder), $M$.; betreten (vom Hahn): petelin kokoš jarči, Cig., C., vzhŠt.; — j. se, sich paaren, falzen (von Vögeln, bes. Hühnern), Z., Cig.; — j. se, schäckern, C. (1/2; Pl.);

júžast - moker ali topel kot odjuga (Po); (- Pl);

kámenščnice - bele hrustave češnje (Po); kámenščica, $f$. die Steinkirsche, vzhŠt.-C.; — neka breskev, kajk.-Valj. (Rad). (1/1; Pl);

kánkole - samokolnica brez korita (Po); kánkola, $n$. pl. eine Art Schubkarren (ohne Truhe), vzhŠt.-C.; - 2) Stelzen, C. (1/1; Pl), kánkole, f. pl. = kankola, Mur. (1/1; Pl);

kóranti - kurenti (Po); korant, $m$. korant je gonjač oračev na pustni dan (ein wild aussehender Mann in rauhem Pelz, mit Hörnern), vzhŠt.-C. (1/2; Pl);

klójci - narezano posušeno sadje (Po); klojəc, -jca, $m$. die gedörrte Obstspalte, die Klötze, Mur., Cig., Jan., SlGor.-C.; — iz nem.; prim. kloca. (1/1; Pl);

kložja - kočarsko pohištvo (Po); klộžje, $n$. Möbel, vzhŠt.-C. (1/1; Pl);

kljúbetnost - kljubovanje (Po); (- Pl);

krmínje - gl. žmikanje (Po); (- Pl);

krplje - priprava, spletena iz vrvce in med dvema locnoma za prenašanje stelje in krme na hrbtu (Po); kŕplja, pl. krplje, ein Netz mit zwei gebogenen Seitenhölzern, die zusammengeschlagen dasselbe schließen; es dient zum Tragen von Heu, Stroh, Streu u. dgl., Mur., Kres, vzh ̌́t.; — (o velikih ustih), C. (2/2; Pl);

ksébni (junec) - junec na levi strani, ob gonjaču; junec na drugi ali na desni strani ojesa je ódsebni (Po); ksébən, -bna, adj. na levi strani idoč: ksêbni konj, das Sattelpferd, Jan. (H.). (1/1; Pl);

kúkerli - okence v steni med kuhinjo in izbo ali hiško (Po); (- Pl);

kúmen - prizidek pri peči (Po); kumən, -mna, $m$. ein Vorsprung beim Ofen, der als Sitz dient, BlKr.; - prim. komen. (2/2; Pl.);

litke - meča (Po); (- Pl); 
ljúdski - tuj (Po); ljûdski, fremd; ljudsko blago; ne hodite za ljudskimi bogovi, Dalm.; gledati po ljudskih ženah, Dalm.; v ljudski deželi, Dalm.; na ljudske stroške, Cig.; posestvo je prišlo v ljudske roke, $Z v$.; ljudske lase nositi, falsches Haar tragen, Polj. (4/4; Pl); mášarji - obiskovalci maš (Po); (- Pl);

mošánčke - rumenkasta pozna jabolka $(\mathrm{Po}) ;(-\mathrm{Pl})$;

nadájati - dojiti (otroka) (Po); nadâjati, -am, vb. impf. ad nadojiti: säugen, C., Volk.-M., ogr.-Valj. (Rad), vzhŠt. (2/2; Pl.);

nájga - pijača iz nagnjenega polovnjaka; tudi v prenesenem pomenu $(\mathrm{Po}) ;(-\mathrm{Pl})$;

nakášati - sproti kositi (Po); (- Pl);

namikávanje - mikastenje z rokami $(\mathrm{Po}) ;(-\mathrm{Pl})$;

nástel - nastil, stelja (Po); nástel, $m$. = nastil, Mik., Valj. (Rad); (nástəł, -stla, vzhŠt.). (Pl);

návek - zmeraj, vedno (Po); návẹk, adv. = zmerom, immer, kajk.-Vest. (1/1; Pl);

návli (v Prekmurju navili) - manjše kopice sena, ki jih natakneš na vile (Po); (- Pl);

oblíkovci - iz okleščenega vejevja nasekana drva (Po); oblíkovəc, -vca, $m$. ein runder, noch unbehauener, unabgezimmerter Baumstamm, V.-Cig.; - der Prügel, SlGor.; okroglo (oblo) poleno, Litija; oblikovci, das ungespaltene Prügelholz, das Knüttelholz, V.-Cig., Pjk. (Črt.), vzh ̌́t.; (nam. oblikavec?). (1/1; Pl);

ódsebni - gl. ksebni (Po); (- Pl);

ókol - ograda za živino (za svinje) (Po); okòl, -kóla, $m$. eine Umzäunung (für Schweine, Schafe), der Viehhof, Mur., Jan., Danj.-Mik., C. (Vest.), Trst. (Let.); - ein umzäunter Weideplatz, vzh ̌́t.; — der eingefriedete Platz um ein Haus herum, SlGor. (1/2; Pl);

óplen - sprednji del voza (Po); oplẹ̀n, -plẹna, $m$. pri vozu na prednji in zadnji premi on les, v kateri sta vtaknjeni ročici, Goriš., Lašče-Erj. (Torb.), BlKr.; der Kipfstock, Cig.; prednji o., der Wendeschemmel, Rib.-M., C.; - tudi prednji in zadnji del voza pri žagi, Notr.; - óplẹn, gen. óplẹna, Goriška ok.-Erj. (Torb.), BlKr.; óplẹn, gen. oplẹ́na, LaščeErj. (Torb.), Śtrek. (1/1; Pl);

ópravka - opravilo okoli živine (Po); (- Pl);

pócje - podstenje (pri hiši ob zidu) (Po); (- Pl);

podójen - pomolžen (Po); podojíti, -ím, vb. pf. ein wenig säugen, ein wenig die Brust reichen: p. otroka; Lepo sinka mi podoji, Npes.-K.; - 2) das Melken vollenden, Mur., Št.; ali si že podojila? Št.; kravo (krave) p., Št. $(1 / 1, \mathrm{Pl})$;

pojdóč - mimogrede (Po); pojdọ́č, adv. = gredoč, unterwegs, im Vorbeigehen, C., vzh ̌́t.; pojdoč jesti, vzh ̌́t;; pojdoč smo mu rekli, Mik. (1/1, Pl);

povèslo - slamnata vez za snope (Po); povę́slọ, n. das Garbenband, Mur., Jan., Mik., Gor.-Erj. (Torb.); - übhpt. ein (nicht eisernes) Band, C. (1/1, Pl);

prášiti - v prahu orati (Po); stauben, sich als Staub erheben; praši se po sobi, po cesti; vino se praši, der Wein perlt, $B l K r$., jvzhŠt. (3/3; Pl);

práva - prav ali desni roka $(\mathrm{Po}) ;(-\mathrm{Pl})$;

préma - (pri vozu) (Po); prẹ́ma, f. jeder der beiden Wagentheile: prednja, zadnja p., Mur., Cig., Jan., Mik., Vrt., Kras, Dol.; - die Lafette, V.-Cig. (1/2 Pl);

préžati - bedeti (Po); pręžati, -ím, vb. impf. lauern, passen; mačka preži na miš; pes preži pri mizi, da bi kaj pograbil; p. na priliko, die Gelegenheit ablauern, Cig.; p. na koga, auf jemanden lauern, jemanden belauern; - bes. ungeladen bei Hochzeiten vor dem Hause lauern (um etwas vom Mahle zu erhaschen); - (pren.) krušne skrbi jim iz obraza preže, Ravn.-Valj. (Rad). (1/1 Pl); 
pripúščanje - pripuščajo se samice (krave, svinje) (Po); pripúščanje, n. das Belegenlassen des brunftigen Viehes: p. živine, ki se goni, Dict. (1/3 Pl);

rájce - fižolovke; $(\mathrm{Po}) ;(-\mathrm{Pl})$;

razceketáti se - razklepetati se (srake cekečejo) (Po); ceketáti, tâm, -ę́čem, vb. impf. $=$ čeketati, $C .(1 / 1 \mathrm{Pl})$;

ročíca - (pri vozu), prednji in zadnji ročici (Po); ročíca, die Handhabe, der Griff, Cig., Jan., C.; r. na meču, Dict.; - die Kurbel, Cig., Jan., Cig. (T.), C., Sen. (Fiz.), DZ.; - der Hebearm in den Mühlen, in der Stampfe, Cig., Notr.; - die Pflugsterze, Cig., Jan., Vrt. $(3 / 6 \mathrm{Pl})$;

sčájmati se - zavesti se, spomniti se (Po); čâjmati se, -am se, vb. impf. allmälig zum Bewusstsein gelangen, zu sich kommen (z. B. aus dem Schlafe, aus der Ohnmacht), Cig., Jan., C.; - gescheit werden, Celjska ok.; sich erinnern, Celjska ok.; - č. se po sv. veri, sich richten, $C$.; - nastalo menda iz: izčajmati se; prim. to in čama. (izčajmati se, $v b$. pf. zu sich kommen, zur Besinnung kommen) Št.-Cig., Jan., C.; izčajmaj se, zaspanec! jvzhŠt.; - zdaj sem se izčajmal = zdaj sem se spomnil, Celjska ok. (1/1 Pl);

sèp - nasipana griva nad gorico $(\mathrm{Po})$; sèp, sépa, sepu, $m$. der Schlag in Weingärten, der Rain zwischen und über den Weingartparcellen, Mur., Danj.-Valj. (Rad), Nov.; bes. der jährlich aufzuschüttende erhöhte Rand oberhalb eines Weingartens, C., Zora, vzh ̌tt.; prim. suti, spem. (1/1 Pl);

skášati - sproti kositi $(\mathrm{Po}) ;(-\mathrm{Pl})$;

skrájnik - prvi ali zadnji ogon (Po); skrâjnik, m. 1) das Schwartbrett, C.; - 2) der Pol (phys.), Cig. (T.); enega skrajnika, unipolar, Cig. (T.). (1/1 Pl.);

slákota - (psovka) (Po); (- Pl);

slovó - prekleto slovo! (psovka) (Po); (- Pl);

snobóki - snubci; (Po); snóbok, -bóka, $m$. = snubok, der Brautwerber, Mur.; v snoboke iti, eine Braut werben gehen, Mur., Valj. (Rad), SlGor.-C.; - gen. tudi: snóboka, Valj. (Rad). (1/1 Pl);

spódnjica - spodnja kikla (Po); spộdnjica, f. der Weiberunterrock, Cig., LjZv., Bes. $(1 / 1 \mathrm{Pl})$;

srednóčke - sredi noči $(\mathrm{Po}) ;(-\mathrm{Pl})$;

stolíca - lesena tesarska štirinožna podloga (konj) (Po); stolíca, $f$. eine vierfüßige, bewegliche Bank ohne Lehne; na stolici stoji čeber, škaf; - die Zimmermannsbank, V.-Cig.; na stolicah hlode tešejo, Gor.-Levst. (Rok.), jvzhŠt.; - die Schnitzbank, C.; - ein langer Kirchen- oder Schulstuhl, ogr.-C., Rez.-Baud.; - die Lehrkanzel, der Katheder, Cig., Jan., C.; - der Thron, ogr.-C.; s. sv. Petra, C.; - der Hauptsitz, Jan.; die Residenz, Mur.-Cig.; - das Comitat, die Gespanschaft, ogr.-Mur., C.; Turoška s., Zora; Železna s., ogr.-C. (1/1 Pl);

sušíce, sušáči - (sušijo krmo) (Po); sušáč, $m$. = človek, kateri seno, lan suši, der Trockner, Mur., Z., C.; - der Obstdörrer, Danj.-Valj. (Rad). (1/1 Pl);

svátrvca - nevestina družica (Po); svátovəc, -vca, $m$. = svat, der Hochzeitsgast, Levst. (Zb. sp.). (1/1 Pl);

Svátrvčnjak - ženinov drug, svatrvčin par (Po); (- Pl);

špížanje nem. - obhajanje, obhajilo (Po); (- Pl);

štalínke - mali hlev, svinjaki (Po); štála, $f$. = hlev, der Stall; - iz nem. (1/1 Pl);

štúrmovka - z žicami zavarovana cilindrasta laterna (Po); (- Pl); 
térja - nora deklina (Po); térjav, adj. dumm, SlGor.; - prim. térəc: der Tölpel, $Z g D$., SlGradec-SlN.; der Narr, Guts. (2/2 Pl);

tetíca - teta (Po); tética $f$. dem. teta. (téta, $f$.) die Mutterschwester, Meg., Alas.; die Vatersschwester, Vod. sp.; die Tante, die Muhme übhpt.) (1/2 Pl);

túkla - jabolčnica iz sadja, stolčenega s pejíči (Po); (- Pl);

túnka - posoda z mastjo in mesom (Po); tûnjka, $f$. dem. tunja; ein kleiner Kübel, $C$.; der Fettkübel, Št.-Valj. (Rad). (1/1 Pl);

újdrč $-\mathrm{s}$ hlevskega stropa viseče in iz desk zbito ležišče (za hlapce) (Po); (- Pl);

vága - pri vozu pod zadnjo premo (Po); vâga, $f$. die Wage am Wagen, woran die Stränge befestigt sind; tudi $p l$. vage, Cig. (2/3 Pl); (beim Wagen: vprežni jermen);

večérko ali večérka - pozno popoldne (Po); večęrka, $f$. der Nachmittag (von 3 Uhr bis zum Abend, C.), Mik., Slom., vzhŠt.; sredi večerke, t. j. med 4. in 5. uro, C.; v večerko, nachmittags, vzhŠt. (1/1 Pl);

víža - napev; način (v prenesenem pomenu) (Po); viža, $f$. način, die Weise (1/2 $\mathrm{Pl})$;

vratník - prostor ob njivi za obračanje (- za vračanje) živine pri oranju (Po); (- Pl);

vrhka - vrh (Po); večęerka, I. adv. obenauf, C.; - II. praep. c. gen., oberhalb: vrhka česa, C. (1/1 Pl);

vrhnje - smetana (Po); vr̂hnje, $n .=$ smetana, das Obers, der Rahm, Guts., Mur., Št.-Cig., Jan., Mik., C.; - prim. nem. Obers. (1/1 Pl);

zarántati $-\mathrm{z}$ rantami ograditi $(\mathrm{Po})$; zarântati, $-\mathrm{am}, v b . p f .=\mathrm{z}$ rantami zapreti ali zagraditi, Cig. (1/1 Pl);

zatúcniti - zaklati (svinjo); v knjigi v prenesenem pomenu (Po); (- Pl);

zdávanje - poroka (Po); zdávanje, n. die Trauung, Mur., C., vzhŠt.-Valj. (Rad). (1/1 Pl); zdíč - (rak ždi v zdiču) (Po); zdič, zdíča, $m$. der erhöhte Ofensitz, Cerkljansko, Temljine (Goriš.)-Štrek. (Let.); - prim. ždič: žděč, -íča, $m$. = naslonjač ob peči, kjer sede posebno stari ljudje, der Sorgenstuhl, Tolm.-Erj. (Torb.); - rak čemi v svojem ždiču (in seinem Versteck), Erj. (Izb. sp.); - prim. zdič. (1/1 Pl);

zizjak - zizno prase; tudi v prenesenem pomenu (Po); (- Pl);

žábe - iz slanine izrezano meso (pri pečenju glasno cvrči, se dere ko žabe) (Po); (- Pl); žóta - nemarno, še zeleno dekle, frklja; (Po); (- Pl);

žmétno - težavno (Po); žmę́ton -tna, adj. = težek, Cig., vzhŠt., Volk., Zora (1/1 Pl);

žmikanje - zažmikana (- skuhana in premečkana) svinjska krma; krmínje (Po); žmíkati, -kam, -čem, vb. impf. pressen, auspressen, ausdrücken; seske ž., Dalm.; grozdje ž., BlKr.; perilo ž., die Wäsche ringen, Cig., Kras, Soška dol., Lašče-Erj. (Torb.); povesma ž., Z.; sir ž., den Käse in Klumpen auspressen, Z. (1/1 Pl).

V romanu Na kmetih je zaslediti tudi nekaj besedja, ki je »neštajerskemu« oz. »neprleškemu« bralcu tuje, avtor pa ga ni zapisal v slovarček, čeprav ne sodi v nabor knjižnega izrazja. Nekaj primerov, katerih raba je s kvalifikatorji $\breve{S}$., $v z h \breve{S} t$. in $j v z h \breve{S} t$. potrjena tudi v Pleteršnikovem slovarju:

bába: zaničljivo o odrasli ženski, posebno starejši; o zakonski ženi (zaničlj.): babo si vzeti, moja baba; = feige Memme, to je baba, ne mož! - die Puppe, Št.-C. (Vest.);

čapljáriti: -arim, vb. impf. herumplatschen, Jan. $\leftarrow$ čâplja, f. der Reiher (ardea), Cig., Jan., Erj. (Ž.), vzhŠt.; ('pljusniti, pljuskati'); 
deklina: dẹklína, $f$. größeres Mädchen, Cig., M.; = dekle, Mur., Jan., vzh ̌̌t.; die Jungfrau, Strek.;

drvena: drvę̂n, adj. hölzern, Cig., Jan.; d. most, Zora;

dverce: dvę́rce, $f . p l$. = durce, Cig., $C$.;

gate: gâte, $f$. = gače, die Unterziehhose; weiße, leinene Beinkleider: poljanci v breškem okraju nosijo ob delavnikih široke bele gate, $P j k$. (Črt.); - prim. bav. gatyen, gati-hosen, madž. gatya, iz slovanščine, Levst. (Rok.);

kajha: kâjha, f. der Kerker, Zora, Št.; - iz nem. Keiche;

kložje: klǫžje, $n$. Möbel, vzhŠt.-C.;

krapavica: krápavica, $f$. die Kröte, Mur., Kres, vzhŠt.;

kravše: krâvše, -eta, n. kleine unansehnliche Kuh, Mur., Cig., Štrek., Št., Vrtov. (Vin.); - pogl. kravišče;

lamentirati: lamentácija, $f$. die Klage, das Klagelied, die Lamentation; ('tožba, žalostinka, elegija, objokovanje');

lampa: lâmpa, $f$. = svetilnica, die Lampe; - iz nem.;

likof: likkof, $m$. die Zeche oder das Mahl, das am Abschlusse einer Arbeit, eines Kaufes u. dgl. gegeben wird, der »Leikauf«; 1. piti, za 1. dati, Vrt., Lašče-Levst. (Rok.); nocoj bomo imeli likof, jvzhŠt.; - der Gelöbnistrunk, Meg., Mik.; - prim. srvn. lītkouf, Mik. (Et.); švab., bav. leitkauf, Levst. (Rok.);

maličko: máličkost, $f$. die Kleinigkeit, Cig.;

nastel: násteł, $m .=$ nastil, Mik., Valj. (Rad); (nástəł, -stla, vzh ̌́t.);

ogon: ogòn, -góna, m. das Ackerbeet, Mur., Cig., Jan., Polj., jvzhŠt.; ógon, -góna, vzh ̌̆t.; pob: pôb, ${ }^{* *} m$. der Bube, der Bursche; - iz nem.;

priklet: príklẹt, $m$. das Vorhaus, Mur., Cig., Jan., C., Danj.-Mik., vzhŠt.; - der Kellervorbau, der Kellerhals, Mur., C.; - (príklet f., Valj. [Rad]);

štimana: štimáti, -âm, vb. impf. 1) meinen, dafürhalten, Mur., Krelj, (štímati) ogr.-Valj. $($ Rad); - 2) schätzen, achten, Mur., Jan.; - š. se, stolz sein, Guts., Cig., M., Št.; š. se s čim, auf etwas stolz sein, jvzhŠt.; - štiman, stolz, hoffärtig, Gor., Št.; - 3) lieben, gern haben: dekleta š.;

žlahta: žlâhta, $f$. das Geschlecht: od žlahte do žlahte, vsa človeška ž., Krelj.

\section{Rezultati analize}

Od 89 geselskih iztočnic jih kar 52 izkazuje narečno rabo v Pleteršnikovem slovarju. 21 geselskih iztočnic je označenih s kvalifikatorjem vzhŠt. "vzhodnoštajersko' (npr. doklič, jarčiti se, kánkole, kóranti, kložja, krplje, nadájati, nástel, oblikovci, ókol, pojdóč, sèp, večérko ali večérka, zdávanje, žmétno), 5 s kvalifikatorjem Št. 'štajersko' (góž, podójen, sčájmati se, túnka, vrhnje), 3 geselske iztočnice z oznako jvzhŠt. ‘jugovzhodnoštajersko’ (góž, prášiti, stolíca), 3 geselske iztočnice imajo oznako kajk. 'kajkavsko' (fáčuk, kámenščice, návek), 3 z oznako V. 'vzhodno' (oblikkovci, préma, stolíca). Pojavljajo se tudi geselske iztočnice s kvalifikatorji SlGor. 'Slovenske gorice' (ókol), Notr. 'Notranjska' (óplen, ročíca), Goriška ok. 'Goriška okolica' (óplen), BlKr. 'Bela 
krajina' (kúmen, óplen, prášiti, žmikanje), Goriš. 'Goriško' (óplen), Dol. 'Dolenjsko' (préma), Celjska ok. 'Celjska okolica' (sčájmati se), Gor. 'Gorenjsko' (povèslo, stolíca, štimana), Cerkljansko (zdič), Temjine (Goriš.) (zdíč), Tolm. 'Tolminsko' (góž, zdíc), Kras (blánja, préma, žmikanje), Soška dol. 'Soška dolina' (žmikanje), Lašče (óplen, žmikanje), SlGradec 'Slovenj Gradec' (térja), vendar vedno le kot dodaten kvalifikator k sicer zapisanim kvalifikatorjem $\breve{S}$., $v z h \breve{S} t$., jvzh ̌́t. 25 iztočnic je brez kvalifikatorja, običajno le z oznako avtorja, ki je besedo uporabljal (npr. bábica, ceketáti, kúmen, ljúdski, povèslo, préma, préžati, pripúščanje, razceketáti se, ročica, skrájnik, slovó, spódnjica, tetíca).

\section{Sklep}

Roman Na kmetih (1954) je Ivan Potrč zapisal v knjižni slovenščini, mestoma pa podkrepil lokalno pripadnost s posameznimi narečnimi besedami z Dravskega polja (čúnika, fáčuk, kámenščnice, kánkole, pócje, rájce, sčájmati se, štalínke, večérko ...). Potrč je na koncu romana sestavil slovarček 89 narečnih besed, kakor jih je občutil on sam, ter jih pojasnil. 70 besed je zaznamovanih z naglasom, in sicer bodisi zaradi različnega mesta bodisi vrste naglasa besed glede na knjižno normo. V pregledu besedja Potrčevega slovarčka (Po) je najprej zapisana avtorjeva razlaga, sledi ji razlaga besedja po Pleteršnikovem Slovensko-nemškem slovarju (P1).

Velika večina analiziranih besed je zapisana tudi v Pleteršnikovem Slovensko-nemškem slovarju (1894-1895), to pa potrjuje prisotnost in živost Pleteršnikovega slovarskega gradiva tudi sredi 20. stoletja. 52 geselskih iztočnic izkazuje narečno rabo v Pleteršnikovem slovarju, od tega jih je največ označenih s kvalifikatorji vzhŠt. 'vzhodnoštajersko', Št. 'štajersko', jvzhŠt. 'jugovzhodnoštajersko', manj pa kajk. 'kajkavsko', V. 'vzhodno', SlGor. 'Slovenske gorice', $\mathrm{v}$ manjšem številu so prisotni tudi kvalifikatorji drugih slovenskih narečnih območij.

\section{VIRI IN LITERATURA}

\section{Viri}

Maks PLETERŠNIK, 1894/1895: Slovensko-nemški slovar. http://isjfr.zrc-sazu.si/pletersnik/. Pridobljeno 10. 5. 2014.

Ivan POTRČ, 2004: Na kmetih. Ljubljana: DZS.

Republika Slovenija. Arhivsko spletno mesto: http://www.arhiv.svlr.gov.si/si/delovna_podrocja/podrocje_lokalne_samouprave/pokrajine/pokrajine_arhiv/index.html. Pridobljeno 10. 5. 2014.

Wikipedia: http://sl.wikipedia.org/wiki/Ivan_Potrč. Pridobljeno 10. 5. 2014. 
Wikipedia: http://sl.wikipedia.org/wiki/Štajerska_(vojvodina). Pridobljeno 10. 5. 2014.

Wikipedia: http://sl.wikipedia.org/wiki/Pokrajine_v_Sloveniji. Pridobljeno 10. 5. 2014.

\section{Literatura}

Jožica ČEH, 2006a: Dialektizmi v Potrčevi prozi. Diahronija in sinhronija v dialektoloških raziskavah. Ur. M. Koletnik, V. Smole. Maribor: Slavistično društvo Maribor. (Zora 41). 183-189.

- -, 2006b: O Potrčevi predvojni pripovedni prozi. Ljubljana: JiS (Tisk. izd.) 51/5, [15]-23. http://www.jezikinslovstvo.com/pdf/2006-05-Razprave-JozicaCeh.pdf. Pridobljeno 10. 5. 2014.

Jožica ČEH STEGER, 2012: O Potrčevi zgodnji kratki prozi. Spremna študija. Ivan Potrč: Prepovedano življenje. Maribor: Litera. (Knjižna zbirka Piramida). 277-304.

Doris DEBENJAK, 2003: Veliki nemško-slovenski slovar [Elektronski vir]. Ljubljana: DZS.

Bogomil GERLANC, 1969: Roman Ivana Potrča v angleščini. Primorski dnevnik, 10. 8. 1969.

France KOBLAR, 2013: Potrč Ivan. Slovenski biografski leksikon. 1925-1991. http://ezb. ijs.si/fedora/get/sbl:2245/VIEW/. Pridobljeno 10. 5. 2014.

Mihaela KOLETNIK, 2007: Besedje v severovzhodnem narečnem prostoru. Besedoslovne spremembe slovenskega jezika skozi čas in prostor. Maribor: Slavistično društvo. (Zora 49). 347-423.

Rudolf KOLARIČ, 1956: Središka govorica in spodnjeprleški govor. Ljubljana: Slavistična revija 9, 162-170.

- -, 1968: Prleško narečje. Svet med Muro in Dravo: ob stoletnici 1. slovenskega tabora v Ljutomeru 1868-1968. Ur. V. Vrbnjak. Maribor: Obzorja. 630-650.

Krajevni leksikon Slovenije, 1995: Ljubljana: DZS. 313-315.

Tine LOGAR, Jakob RIGLER, 1993: Karta slovenskih narečij. Karto priredila: Tine Logar in Jakob Rigler na osnovi Ramovševe Dialektološke karte slovenskega jezika, novejših raziskav in gradiva Inštituta za slovenski jezik ZRC SAZU. Besedilo: Tine Logar. Ljubljana: Založba Mladinska knjiga. Zvd.

Dušan MEVLJA, 1993: Ivan Potrč - osemdesetletnik. Knjižni razgledi 10, 15 (19. 1. 1993).

Maks PLETERŠNIK, 2006: Slovensko-nemški slovar: (1894-1895). Elektronski vir, CD ROM. Ur. Metka Furlan, Helena Dobrovoljc in Helena Jazbec. Transliterirana izd. Ljubljana: Založba ZRC, ZRC SAZU: Amebis. http://isjfr.zrc-sazu.si/pletersnik/. Pridobljeno 10. 5. 2014.

Bernard RAJH, 1999: Nekatere naglasne premene v oblikoslovju severozahodnega prleškega govora. Logarjev zbornik: referati s 1. mednarodnega dialektološkega simpozija v Mariboru. Ur. Zinka Zorko, Mihaela Koletnik. Maribor: Slavistično društvo. (Zora 8). $137-147$.

- -, 2001: Cerkvenjaški govor. Podobe kraja: zbornik Občine Cerkvenjak. Ur. Bernard Rajh, Marjan Toš. Cerkvenjak: Občina: Slovenskogoriški forum. 259-277. 
- -, 2002: Gradivo za severozahodnoprleški narečni slovar. Med dialektologijo in zgodovino slovenskega jezika: ob življenjskem in strokovnem jubileju prof. dr. Martine Orožen. Ur. Marko Jesenšek, Bernard Rajh, Zinka Zorko. Maribor: Slavistično društvo Maribor. (Zora 18). 117-123.

--, 2003: Besedje in besedne zveze v severozahodnoprleškem govoru. Glasoslovje, besedoslovje in besedotvorje v delih Jakoba Riglerja. Ur. Zinka Zorko, Mihaela Koletnik. Maribor: Slavistično društvo Maribor. (Zora 25). 118-134.

--, 2004a: Vzhodnoštajersko besedje v Pleteršnikovem slovarju. Besedoslovne lastnosti slovenskega jezika: slovenska zemljepisna imena. Ur. Marko Jesenšek. Ljubljana: Slavistično društvo Slovenije; Pišece: Društvo Pleteršnikova domačija. 225-230.

- -, 2004b. Besedno prevzemanje iz nemščine v severozahodnoprleški govor. Ann, Ser. hist. sociol. 14/ 1, 195-202, zvd.

- -, 2005: Severozahodnoprleška osebna imena. Knjižno in narečno besedoslovje slovenskega jezika. Ur. Marko Jesenšek. Maribor: Slavistično društvo Maribor. (Zora 32). 98-105.

--, 2006: Glagoli v severozahodnoprleškem govoru. Diahronija in sinhronija v dialektoloških raziskavah. Ur. Mihaela Koletnik, Vera Smole. Maribor: Slavistično društvo Maribor. (Zora 41). 399-406.

--, 2008. Tipologija in razvrstitev naglašenih samoglasnikov v severozahodnoprleškem govoru. Škrabčeva misel VI. Zbornik s simpozija 2007. Ur. Jože Toporišič. Nova Gorica: Frančiškanski samostan Kostanjevica. [81]-99.

- -, 2010: Gúčati po antùjoško: gradivo za narečni slovar severozahodnoprleškega govora. Maribor: Mednarodna založba Oddelka za slovanske jezike in književnosti, Filozofska fakulteta. (Zora 73).

Bernard RAJH, Melita ZEMLJAK JONTES, 2005: Instrumentalno-slušna določitev samoglasniških sestavov obrobnega prleškega govora. Glas. ZRS Koper 10/3, 32.

Fran RAMOVŠ, 1931: Dialektološka karta slovenskega jezika. Rektorat Univerze kralja Aleksandra I - J. Blasnika nasl. Ljubljana: Univerzitetna tiskarna.

- -, 1935: Historična gramatika slovenskega jezika VII. Dialekti. Ljubljana: Učiteljska tiskarna.

Jakob RIGLER, 1981: Videm ob Ščavnici (OLA 20). Fonološki opisi srpskohrvatskih/ hrvatskosrpskih, slovenačkih i makedonskih govora obuhvaćenih opšteslovenskim lingvističkim atlasom. Ur. Pavle Ivić idr. Sarajevo: Akademija nauka i umjetnosti Bosne i Hercegovine. 173-177.

Jožica ŠKOFIC, 2004: Fonološki opis govora Juršincev v Slovenskih goricah (SLA 378). 103-119. file:///C:/Users/Uporabnik/Downloads/URN-NBN-SI-doc-JO00WRK5. pdf. Pridobljeno 10. 4. 2014.

Bojan ŠTIH, 1954: Ivan Potrč - Na kmetih. Naša sodobnost 2/9, 848-856.

Alenka VALH LOPERT, Mihaela KOLETNIK, 2011: Mariborščina kot identitetni dejavnik v radijskem diskurzu. Časopis za zgodovino in narodopisje 82=47/1, 121-134

Alenka VALH LOPERT, Melita ZEMLJAK JONTES, 2013: Potrčev roman Na kmetih v Pavlovićevem celovečernem filmu Rdeče klasje. Časopis za zgodovino in narodopisje $84=49 / 2-3,169-202$. 
Zinka ZORKO, 1998: Haloško narečje in druge dialektološke študije. Maribor: Slavistično društvo Maribor. (Zora 6).

--, 2009: Narečjeslovne razprave o koroških, štajerskih in panonskih govorih. Maribor: Filozofska fakulteta, Mednarodna založba Oddelka za slovanske jezike in književnosti.

\section{POTRČ IN PLETERŠNIK'S DICTIONARY (NA KMETIH/THE LAND AND THE FLESH, A NOVEL WRITTEN IN 1954)}

Ivan Potrč (1913-1993) was born the second of ten children in Štuki near Ptuj in a family of farmers. The writer's work is distinguished by a diversity of creative themes. In particular, he tried to depict the little man, his hardships, and the peasant life of shortage and hard work, substantiated with a sharpened sense of human destiny.

His personal and writing affiliation with Ptujsko polje (Ptuj Field), Haloze, and Slovenske Gorice (Slovenian Hills), particularly with Ptuj, stands out. The novel presents the confession of Južek Hedl, who tells his life story from jail. Due to a dispute with his sister Lisa and her husband Štrafela as well as with his mother regarding domestic property, Južek left his homestead and became a farmhand at the neighbouring Toplek's farm.

At first he got involved with the older Toplečka, a widow, and she gave birth to his child; he then became involved with her oldest daughter Hana, who also became pregnant. Južek realized that he would not be able to become master of his family estate nor the Toplečka's farm. He strangled Toplečka and ended in prison. Južek fell in love with Toplečka's youngest daughter Tunika, but a relationship between them didn't develop. She, however, loved him. Hana and the two children (her mother's and her own) waited for Južek to return from prison.

Ivan Potrč wrote the novel Na kmetih/The Land and the Flesh (1954) in Standard Slovene and partly gave the novel a local feel by using individual dialectal words from Dravsko polje (Drava Field): čúnika (pig), fáčuk (child), kámenščnice (a variety of cherry), kánkole (wheelbarrow), sčájmati se (to come up with), štalínke (small stables), večérko (evening) etc.

The majority of the words analyzed are also present in the Pleteršnik's Slovensko-nemški slovar (Slovenian-German Dictionary, 1894-1895), which confirms the presence and vitality of Pleteršnik's lexical material even in the middle of the $20^{\text {th }}$ century. 52 of the entry cues demonstrate the use of dialect in Pleteršnik's Slovensko-nemški slovar, with most of them bearing the qualifier vzh ̌́t. 'vzhodnoštajersko' (North-Eastern Styrian), Št. 'štajersko’ (Styrian), jvzh ̌̌t. 'jugovzhodnoštajersko' (South-Eastern Styrian), just a few kajk. 'kajkavsko' (Kajkavian), V. 'vzhodno' (Eastern), SlGor. 'Slovenske gorice' (Slovenian Hills), as well as qualifiers from other dialect areas. 